\title{
Language and Madrasa in India, Uttar Pradesh
}

\author{
Arina Rohmatika \\ IAIN Surakarta, Indonesia \\ e-mail: arinarohmatika@gmail.com
}

\begin{abstract}
Data shows that Muslim population in India, at the census 2001, was in second place after Hindus. It reached 138 million (13.4\%) after Hindus which is little over 827 million (80.5\%). This number implies how Islam has been well-received in India and entered into various areas of life including education. Muslim Educational System in India has developed over decades through its Islamic institution and madrasas. This study aims to see the language teaching in Darul Uloom, Deoband as it is reflected through its educational system and curriculum. This is a library based research in which extensive reviews of literature has been made in attempt to produce a descriptive qualitative analysis. This study shows that in Darul Uloom Deoband, stylized writing mastery has become the ultimate skills to acquire. Here, Language is not only merely targeted as a means of communication but also as a means to study Islamic textbooks. Moreover, it is expected that through the language mastery its students and alumni can be author of many books in Arabic and English. Language is learned comprehensively started from grammar, syntax, to Literature.
\end{abstract}

Keywords: Language, Madrasa, Darul Uloom Deoband 


\section{Introduction}

Islam has recorded its long history in India. Based on the result of the census issued by Ministry of Home Affairs, Government of India in 2001, Islam was the second biggest religion in India, coming after Hindu. Out of 1028 million of total population, it reached 138 million (13.4\%) after Hindus which is little over 827 million (80.5\%). Christians, Sikhs, Buddhists, Jains and others share smaller numbers than Moslems Moreover, related to the muslim educational system, Islamic pattern of education has started to develop in the eight century, before the muslim rules developed in India. By the middle of thirteen century, Delhi became the center of Muslim learning in the east.

This is a library based research in which extensive reviews of literature has been made in attempt to produce a descriptive qualitative analysis. The object of the study is Darul Uloom Deoband, Uttar Pradesh, India. The data was taken through documentation and observation and analyzed by using triangulation data analysis. Eventually, a description about language and madrasa in India is the aim of study presented in this article.

There were several periods related to the development of Islamic educational systems in India. the first is The Delhi Sultanate Period (1290 - 1296). in this period, many mosque schools were built where religious education was penetrated to the general public. The Tughlaq dynasty (1320-1414) is the next dynasty that gives a lot of education and scholarship. in this era, Muhammad Bin Tughlaq arranged to teach all subjects of Arts and Science. In the next dynasty, The Lodi dynasty (1451-1526) many important contributions were made towards eduactional policy and resulted in many developments in the existing education system. they believe that promoting education is part of their playing duty and tasks. Furthermore, in the Mughal Period, the rulers made a new history in Muslim education. they brought about Delhi as the most important seat of Muslim education in Northern India. in this era a madrasa was established in Delhi that taught many subjects ranging from mathematics to the theological subjects. up to Akbar's reign, Muslim educational systems were relatively unchanged, both in terms of curriculum or in teaching methods. however, there were some shortcomings in this period, namely the existing curriculum still focused on theological matters and alot of courses of the scope of Islamic Studies received little attention and the second teaching method was hard to understand and outmoded.

In Akbar's era, several colleges were successfully built in Agra, Fathepursikri, Lahore, Delhi and other important towns in his empire. During this period, the study of 
Sanskrit and Sanskrit literature were also introduced. The method of teaching was focused on creating teacher independent students in studying .Moreover, in this era, language translation for religious learning interests had been developed a lot; from Sanskrit and Arabic into Persian. After the conquest of Gujarat, the opportunities for Arabic learning, Hijaz for instance, were opened widely to the Muslim of India. Through this, the study of hadith had increased because Arabic beocame a means to facilitate Muslims to understand religious courses. In addition, in this era, Muslim educational institutions had two models; they were a Maktab (a primary or secondary education) and Madrasas or institution of Higher learning.

The presence of the British rulers had brought significant changes to the education system in India including madrasas, Maktab and many institution of higher learning. Some of these changes are restrictions on the use of money for education because they tend to be comercial oriented. Moreover, missionarries Christians were allowed to preach in India. Further big impact on the development of Islamic educational systems in India especially in language teaching happened when the President of the Board of Control, Sir Charles Wood, sent a despatch to Lord Dalhousie back then in 1854. It became an important issue and gave huge effect on spreading English learning in India which formed the basis of the current educational system.

Back then, Wood suggested that English was to be used as the medium of instruction in education, well known as Wood's despatch. This Wood's despatch on education focused on spreading the application of the use of English and Local languages throughout the country. through this, they also wanted to promote the western education pattern in order to develop education system in India. To sum up, the dissemination of the European knowledge was the motto of the Wood's Despatch. According to it, for the higher education, the chief medium of instruction would be English. this idea, however, had brough about the westernization of the educational system in India. Through this, the English language was initially formally learned massively in Indian educational systems.

Based on those facts explained, it can be seen that how language seen and treated has relationship of the education system in India. furthermore, the above phenomenon also shows how Islamic education system develops and evolves. How it became a big part of that development. Language not only has a role in facilitating communication but also become a tool for deepening religious knowledge and strengthening political influence. Thus, this study specifically discusses about the teaching in madrasas reflected through 
its curriculum and the role of those languages in the development of Islamic educational institutions in India, especially in the institution of Madrasa. More specifially, this study is focused on Madrasa of Darul Uloom deoband, Uttar Pradesh India.

\section{Discussion}

\section{Language Learning in Madrasas}

Arabic language came to India during the eighth century and then flourished during the late fifteenth century and in the beginning of 16th century. In India Arabic language was introduced in Indian Civil Services examination as early as 1963 for the first time and it became an optional subject to be taken at the preliminary stage of the examination from there onwards (Khan, 2013). The Arabic language came to India through Arab Muslim settled Sind, western Indian Province. That was the first contact made by Indian and Arabic language. Furthermore, under the era of the Mughal rulers, the Arabic language continued to develop further. India has long had a relationship with the Arab world since the eleventh century and during the hundreds of years after, there were many major dysnasti which originated from northen India. Mughal dynasty for example, in this era, Mughal court used Persian and many other languages. This is quite well known that during this dynasty, many loan-words from Arabic Farsi, and Turkish in Hindi / Urdu, the lingua franca of much of northern India and Pakistan. (Owens, 2011). In most of India's madrasas, there are three languages commonly taught; they are Arabic language, English language and local language. In madrasa Darul Uloom Deoband itself, Urdu is taught as the local language. However, among those three, Arabic has a long history related to Islamic education system in India. It has been taught far before English.

Over the centuries, the need to learn Arabic increased among Indian Muslims. They wanted to learn it for the sake of their religious needs. Thus madrasas and religious school has been part of Teaching Arabic as Language of Religion in India. religious schools called maktab and madrasa focused only for Muslim students. A quite comprehesive desription about arabic teaching is given by Owen who stated that the curriculum followed in these madrasas through the centuries focused on Islam as a subject while Arabic language as a tool. Moreover, grammar-centered and text-oriented teaching method became the most widely used for Arabic teaching in these madrasas. They focus more on reading and understanding classical Arabic texts rather then on speaking skills which are less emphasized. Stylized prose writing skills are given more spots and attention (Desai,1978). 
In this era, memorization of the targeted language had been a favourite method to be used until British colonial era where its government focused on spreading out English language and de-emphasized religious study center such as maktaba and madrasas. Secular learning Institution had been developed by British rulers meanwhile Arabic language in those institutions was initially somewhat marginalized in terms of modified curriculum teaching method

As a reaction to the conditions, many modernist Muslims made a change effort so three Muslim-style modems emerged, all of which were open to Muslim and non-Muslim students; they are Aligarh Muslim University which is considered as the first Muslim institution implementing secular learning, founded in 1875 in Aligarh, Uttar Pradesh, The Jamia Millia Islamic modem founded in 1920 in Aligarh which later moved to Delhi in 1925. This jamia aims to create secular education simultaneously with religious education. The third is Jamia Osmania University established in 1917in Hyderabad, Andhra Pradesh,. In these three universities Arabic was studied and formally developed even until now in the twenty first century. Besides of being studied in Islamic universities, Arabic is also studied in madrasas.

The following are some of the well-known madrassas among the madrasas that exist in India which focus on teaching Arabic first, Jamiatul Falah It was started as a primary school to standard which later became Jamiatul Falah. It is located in Bilariyaganj, Uttar Pradesh. Secondly, Al-Jamia al-Salafia - It was founded in 1963. It is located in Banaras, Uttar Pradesh. Thirdly, Jamia Islamia Sanabil - At Joga Bai, New Delhi in 1980. Fourth, Darul Uloom - It is located in Umrabad, Maharashtra and fifth Al-Madrasa Al-Islamia It is located in Shahi Muradabad, UP. Presently, in India, Arabic language is also being taught and learned in more than twenty thousand Madarsas, mostly in Northern and some Western parts of India. Deobandh and Nadva-tul-Ulum has emerged as the major centres of learning of Arabic language in the form of recitation of Quran and Hadith (Khan, 2013). Thus, madrasas have been functioned as the centre of arabic language teaching and learning since decades in India till present days where thousands madrasas still exist and teach this language. Arabic is now being taught in schools especially schools with Islamic orientation such as in Deobandh and Nadva.

The most famous educational institution of Islamic and Arabic studies that came into being during this period is Darul Uloom Deoband where the Deobandi Islamic movement was firstly initiated. It was founded in 1866 in Saharanpur of Uttar Pradesh state by some 
prominent Islamic scholars including Maulana Muhammad Qasim Nanotvi, Maulana Rasheed Ahmed Gangohi and Haji Saiyyid 'Abid Husaiyn. It has produced since then hundreds of scholars who have earned name and fame in Arabic language and Islamic studies and authored many books in those connected subjects (Rahman, 2014). to sum up, Arabic is no longer considered to be the language of a religion, rather it is also used as a medium for spreading religion and toughts through writings too. Many scholarly valuable research works have been produced and are being produced by Indian scholars from madrasas and universities.

Another language which has given great influences in India's madrasas is English. Historically, English becomes widely spoken and learned in India since British colonization. English took over Indian languages with the coming of the colonial rule. Gradually, it became part of the curriculum in academic institutes and language of communication of the elite. Regardless its long history, teaching English in India has never been easy. Till the present days, it still faces many obstacles and challenges either related to the students and the teachers (Kalia, 2017). For instance, The majority of Indian rural students, especially in the states of Bihar, U.P. and Maharashtra, find English as a very difficult subject to learn. They are still dependant to the help other other greatly. They need the guidance from parents and others. (Roy, 2017).

Back then in the era of British colonization, when English was required to be studied, they thought that it was intended not only to make English as a medium of instruction but rather as a means of carrying out Christianization. consequently, Muslims are far behind Hindus in English Education (Ramzan \& Rabab, 2013). Later on, though its policy, British government has presented English as second language needs to be studied by indian students untill know. English has become the most used language to communicate after Hindi. besides, it likely becomes the most read and composed language in India. English symbolizes in Indians minds, better training, better culture and higher mind. Indians who speak English regularly blend it with Indian languages in their communication. It is quite common among Indians to suddenly switch to talk familiar English amidst their discussions. Additional information is available in the communicator among Indians who talk a distinctive language. English is very critical in a few frameworks - lawful, money related, instructive, business - in India. This phenomenon illustrates how English has entered many lines in India including education. The British arrangement was to make an Indian class who ought to think like the English, or as it was said then in Britain "Indians 
in blood and shading however English in taste, in sentiments and ethics and judgment" (Tanzeel, 2017).

Making it as the language of the government, english language holds its important role in India nowadays including in Madrasas where Arabic language has been the core of language learning. How English language taught and presented in Madrasa becomes an interesting issue in which in the past english language was closely to westernization. In prominent Madrasas such as Darul Uloom Deoband, English language is taught not only for communication tool but also for sharpening their knowledge towards the language itself. It ca be seen how English literature is included as a cumpolsory subject.

Besides Arabic and English language, Urdu is another language which is used in many madrasas including Darul Uloom Deoband in Uttar Pradesh, India. During the Mughals and its immediate successor states, Persian was widely used as the language of the royal courts, higher levels of administration and diplomacy. Later, by implementing the colonial rule, the British abolished Persian for then replaced it with English in 1836. Consequently, every state in India has to provide primary education in mother tongue. Uttar Pradesh contains the largest number of Urdu speakers. (Khalidi, 2010)

Urdu is the local language commoy used in Uttar Pradesh. Generally, its biggest speakers come from western Uttar Pradesh. This local language is frequently used for daily communication and everyday conversation. Urdu itself was a new language evolved from the language of Western Uttar Pradesh Region, Khadiboli and Braj Bhasha which were dialects of Hindi language with the language of muslim rulers who came to India and ruled over this region (Malik, 2018). This local language is also used and taught in Education field including in Madrasa Darul Uloom deoband and many other madrasas. Regardless of exact numbers, the madrasas play a major part in Urdu literacy since it has been used as language of instruction in many madrasas in most states of India. Only few madrasas use other local languages such as Kerala, Tamilnadu and West Bengal madrasas. In those states, Malayalam, Tamil, and Bengali are used. However, in general Urdu has been applied as the language of instruction in madrasas. What makes it interesting is that as stated by Malik that it is not the purpose of madrasa to specially cspromote Urdu, but given that literature on Islam in it is unrivalled by any Indian language, Urdu is the natural choice as the medium of madrasa education. In the other words, Urdu is used and functioned merely as language instruction in madrasas without any specific target to develop it and bring it into another higher level. This phemonenon also happens alot to 
many other local language in other countries including indonesia in which local language such as javanese used as language instruction in many conventional madrasas (Pondok Pesantren).

\section{Language in Curriculum of Darul Uloom Deoband}

Established on 30 May 1866 by Muhammad Qasim Nanautavi and Rashid Ahmad Gangohi who were the principal founders of the seminary, darul Uloom Deoband is today a religious center and academic center in the Islamic world. it is the largest institution for dissemination and propagation of Islam and the biggest head of education in the Islamic sciences. Besides the Jam'a-e Azhar, Cairo, there is no institution anywhere in the Islamic world that has acquired importance in terms of antiquity, resorting, and the strength of students as the Darul Uloom, Deoband, has. It is even dependent from the government in terms of finance and curriculum.

Furthermore, In response to the vibrant trend of educational reform in madrasas in India, Darul Uloom Deoband has upgraded its curriculum by adding two new departments of learning English as a second language and computer literacy courses. Upon successful completion of the given stage, students receive certificates for admission in mainstream schools. Some madrasas encourage their students to enter into vocational training or small trade.(Talib, 2017). However, as Sikand (2005) states that thing to highlight is that the aim of the madrasa is different from that of a modern school. only way to pass judgment on the madrasas is to see how far they have been able to achieve their own aims, such as inculcating piety, promoting religious knowledge, control over the base-self (tahzīb-i nafs) and service of others. Therefore, no suggestion for reform of the syllabus that goes against those aims is acceptable. (Sanyal, 2019). Moreover, the modernization of the madrasah entails incorporation within the curriculum such subjects as science, math, English, Hindi, and social studies. This is to bring madrasah curriculum on a par with the mainstream subjects.

Related to its education system, it is found that this madrasa has a quite unique form of school level. In general it has two main courses which are a compulsory Eight year level of school and a non compulsory post- graduate. Any graduate student from the eight year course of the Arabic classes who is interested in mastering further topic or subject can take admission in the post-graduate class and continue his education after receiving the graduate degree (Sanad-e-Faraghat) of Darul Uloom. Other post graduate programs 
are also available such as Mastery in Computer Mastery in Training for Teaching Mastery in Tajweed w Qira'at, Mastery in Calligraphy, Mastery in English literature Mastery in Journalism, Mastery in Dawah and many others.

The curricula of these madrasas include the subjects of Hadith, Commentary on Qur'an, Jurisprudence, Arabic literature, composition, history of Arabic literature, Arabic grammar, Hindi, Urdu \& English languages, rhetoric and so on. Most of the books on these subjects excluding languages are being taught in Arabic language after secondary level. These madrasas produce hundreds of scholars of Arabic language and Islamic studies every year who settle down throughout the length and breadth of the country with considerable command over Arabic language in terms of reading, writing and speaking.

Some of the products of these madrasas have international reputation thanks to their valuable work in Arabic language. Mention may be made of Mohammad Rabey Hasan Nadwi (born 1929), a writer of nearly 30 books in Arabic and Urdu and present rector of Darul- uloom Nadwatul Ulama, and Maulana Syed Salman Husaini Nadwi (b. 1954), a fluent \& eloquent Arabic orator and a successful author of several books in Arabic and Urdu, and Dr Muqtada Hasan al-Azhari who has more than 40 books to his credit in Arabic and Urdu (I have compiled a book about him in Arabic with title "Dr Muqtada Hasan Al-Azhari: His life and contribution to the Arabic and Islamic Studies"), and Maulana Abdur Rahman Fariwayi who has written around 17 books in Arabic and edited around 40 books, and Maulana Luqman Salafi, an author of more than 10 books in Arabic and Urdu.(Rahman, 2014)

Having examined the above curriculum, it can be seen that this madrasa strongly emphasizes language teaching since the early stage of the school levels. Urdu, Arabic and English are given simultonously. Moreover, from its syllabus, it can be seen that Arabic language is the main focus among those languages. this is because the majority of the books studied are in Arabic, meanwhile Urdu is taught and used as the language of instruction during the classes. English is also included in the syllabus of the curriculum. Previously, English was taught because of the rule from the British period which tried to reduce and replace the Arabic language's influence and spread. Later, it turns out to get better attention. It can be seen from its post graduate courses which include mastery in English Literature. A policy which is quite different from madrasas from other Islamic countries such as Indonesia that generally does not study English Literature.

At:t|Volume. 4, No. 1, Januari-Juni 2019 
Another notable interesting fact about its policy related to language in its curriculum is that, the teaching of the language such as Arabic and English is not merely focus speaking and reading. It gives great emphasis on Writing. It seems that the madrasa targets its students and alumni to be able to write Islamic books in bot arabic and English in such a stylish way. This purpose is well understod because since the beginning of its madrasa, the achievements of the Ulama of the Darul Uloom in the fields of religion, education, missionary work and book writing have been acknowledged repeatedly. It is not only in India but also in other Islamic lands, and in the fields of guidance and instruction, teaching and preaching they seem to be ahead of all others.(Neyazi, 2015). This kind of tradition makes Darul Uloom Deoband emphasizes the language learning in its curriculum and have a pretty high standard on it. The eight-year course in Arabic language proves that this madrasa wants to make sure that its students have sufficient and comprehensive level of language skills and mastery.Moreover, Journalism course also shows that advanced laguage level is targeted by its madrasa. To Sum up, language learning becomes a priority in this madrasa in order to reach targeted purpose in learning Islamic science and studies.

\section{Conclusion}

Language learning in India has a long history which is related to not only education but also politics. In madrasa darul Uloom Deoband, Uttar Pradesh India, language plays an important role. It is learned as a means of communication and a means to study Islamic Science and studies. Related to the syllabus itself, the language learning has the biggest part of its courses. Even, students are given study of hadits in the eighth year after they have mastered Arabic Basics. Moreover, Related to the skills focused, this madrasa focuses more on writing. Being able tocommunicate in Arabic and English is not enough, they have to reach the skills of being an author of Islamic books and contribute to the development of Islamic studies around the globe just like its tradition so far for having produced many great and influential scholars and authors aroudn the globe. Journalism course also proves that Darul Uloom Deoband focus on writing skills.

Another interesting fact found in Madrasa Darul deoband is its language teaching syllabus which range from Grammar, syntax up to literature. Literature has been introduced since early stage of the study. It is aimed at getting the students to get familar with literature as early as possible so that later on they can be a writer or author which has a high quality of stylized writings. To sum up, it can be concluded that madrasa 
Darul Uloom deoband has a very high concern about language teaching. It realizes that language is prominent, crucial and fundamental so that it is taught and arranged in such a way in through its syllabus and curriculum. This kind of language curriculum can be used as comparision to other madrasas around the world especially when they have the same aims and purposes as Madrasa Darul Uloom Deoband, Uttar Pradesh, India.

\section{Bibliography}

Chapter - I Development of Muslim Education. (n.d.) retrieved from https://sg.inflibnet. ac.in

Ministry of Home Affairs, Government, India (2001). Retrieved from http://ensusindia.gov.in/Census_And_You/religion.aspx

Darululoom-deoband at http://www.darululoom-deoband.com/english/

Kalia, P. (2017). English Language Teaching in India : Trends and Challenges. IJEAST, 2(3), 33-37.

Khalidi, O. (2010). URDU LITERACY IN INDIA, ودراخــروير رمع يـدلاخ 2010 Massachusetts Institute of Technology, 10(October), 25-149.

Khan, S. hasan. (2013). Arabic Language Teaching in India : Its Place and Scope in the Present Indian Higher Education * Dr . Shazli Hasan Khan Keywords: Arabic Language, Arabic Language Learning, Multicultural Approach, ICT in Teaching and Learning Arabic language proficien. Indian Journal of Research PARIPEX, (May), 73-77.

Malik, N. (2018). Use of Address Terms in Urdu as Spoken in Western Uttar Pradesh (Specially in Rampur and Adjoining Districts): A Sociolinguistic Study, 18 (49042), $154-164$.

Neyazi, T. A. (2015). Darul Uloom Deoband: stemming the tide of radical Islam in India . This document is downloaded from DR-NTU, Nanyang Technological University Library, Singapore. Author (s) Rights, (July).

Rahman, M. (2014). Arabic in India: Past, Present \& Future, 14 (December), 290-306.

Roy, N. (2017). Challenges in Indian Classrooms to teach English as a Second Language. International Conference on ICT for Language Learning, 1-3.

Sanyal, U. (2019). Yoginder Sikand, Bastions of the Believers. South Asia Multidisciplinary Academic Journal, (April).

Talib, M. (2017). Islamic Education in India. Handbook of Islamic Education, International Handbooks of Religion and Eduaction 7, 1-17. https://doi.org/10.1007/978-3-31953620-0

Tanzeel, S. (2017). About Us | Editorial Board | Submission Guidelines | Call for Paper Paper Submission | FAQ | Terms \& Condition | More ....... Postcolonial Ethos in the poetry of Nissim Ezekiel. Ijellh, $V(\mathrm{X}), 790-798$.

At-t: | Volume. 4, No. 1, Januari-Juni 2019 